\title{
Th17 cells in mucosal immunity and tissue inflammation
}

\author{
Jay K. Kolls
}

Received: 9 January 2010 / Accepted: 29 January 2010 / Published online: 25 February 2010

(C) Springer-Verlag 2010

\begin{abstract}
T helper type 17 (Th17) cells are a distinct lineage of T cells that produce the effector molecules IL-17, IL-17F, IL-21, and IL-22. Th17 cells have been shown to have critical roles in autoimmunity and tissue inflammation. However, emerging evidence also shows these cells are critical regulators of host immunity against bacterial, fungal, and viral infections at mucosal surfaces. Moreover, these cells can be induced following vaccination and have been shown to be critical for vaccine efficacy against both extracellular and intracellular pathogens. In this issue, we summarize recent progress in our understanding of the function of Th17 cells and where these cells fit in protective immunity and immunopathology.
\end{abstract}

\section{Introduction}

CD4+ T helper cells are critical cells that mediated adaptive immune responses. As evidence of this, their progressive loss in the setting of HIV disease is closely linked to the development of opportunistic infections [1,2] such as Pneumocystis pneumonia. In fact, it was recognized shortly after the initial description of AIDS that the primary immunodeficiency was loss of circulating CD4 $+\mathrm{T}$ cells and that the risk of opportunistic infection with many pathogens was directly related to the severity of the CD4+ $\mathrm{T}$ cell deficiency [1]. Four years after the initial description of AIDS, Mossmann and Coffman described the first two CD4+ $\mathrm{T}$ cells subsets based on the ability of these cells to

J. K. Kolls $(\square)$

Department of Genetics, LSU Health Sciences Center,

533 Bolivar St,

New Orleans, LA 70112, USA

e-mail: jkolls@1suhsc.edu produce a distinct profile of cytokines [3]. Cells that produced interferon-gamma were termed Th1 cells, and cells that produced interleukin (IL)-4, IL-5, and IL-13 were Th2 cells. This dichotomous paradigm has been validated in several mammalian species. Further evidence that these cells represent distinct lineages is the fact that their differentiation from naive $T$ cells requires distinct transcription factors, STAT 4 [4-6] and T-bet [7] for Th1 cells and STAT6 $[8,9]$ and GATA-3 $[10,11]$ for Th2 cells.

This dichotomy of $\mathrm{T}$ cell subsets was the basis of $\mathrm{T}$ cell immunology for nearly 20 years. However, this dichotomy of $\mathrm{T}$ cell subsets could not fully explain the infections seen in congenital or acquired absence of CD4+ T cells such as mucosal candidiasis, Pneumocystis carinii pneumonia, or some bacterial pneumonias. For example, mice deficient in Th1, Th2 responses (or both) are not permissive for $P$. carinii pneumonia [12], a hallmark infection in AIDS patients with low $\mathrm{CD} 4+\mathrm{T}$ cell counts. Moreover, while mice deficient in IL-12p40, a molecule known to drive Th1 responses, were protected against autoimmune inflammation such as experimental autoimmune encephalitis, mice deficient in the hallmark Th1 cytokine, IFN $\gamma$, or the other IL-12p35 subunit were not [13]. Taken together, these data suggested that other CD4+ T cell lineages must exist, and these cells must play critical roles in autoimmunity but also in host defenses against opportunistic infections.

Data from a number of laboratories now have clearly changed the traditional paradigm of Th1/Th2 cells. In addition to these effector $\mathrm{T}$ cells, a third subset of $\mathrm{T}$ cells as emerged referred to as Th17 cells [14-17]. Th17 cells produce the cytokines IL-17A (IL-17) $[14,15]$ and IL-17F [16], as well as the cytokines IL-21 [18, 19] and IL-22 [20, 21]. This new Th17 cell lineage fills in many of the missing gaps in host immunity not fully explained by the Th1/Th2 paradigm. 
In this issue of Seminars in Immunopathology, we address key issues regarding Th17 cells. What controls their development? What are the positive and negative signals that regulate their fate, survival, and establishment of memory? What regulates the expression of their main effector cytokines IL-17A, IL-17F, and IL-22? What are the requirements for these ligands to signal and in what tissues? What role do these cells play in autoimmune inflammation in the mucosa (gut) and non-mucosal sites such as the central nervous system? Lastly, what is their role in host defense, and can Th17 cells be exploited by vaccination strategies to enhance immunity against various pathogens? In summary, we believe this issue is timely and will be a useful review of our current understanding of Th17 cells and hopefully, will serve as a basis to push the field forward.

Acknowledgements Funding for this project was provided, in part, by P50HL084932 and R01HL079142.

\section{References}

1. Phair J, Munoz A, Detels R, Kaslow R, Rinaldo C, Saahet A (1990) The risk of Pneumocystis carinii pneumonia among men infected with human immunodeficiency virus type I. N Engl J Med 322:155-161

2. Morris A, Lundgren JD, Masur H, Walzer PD, Hanson DL, Frederick T, Huang L, Beard CB, Kaplan JE (2004) Current epidemiology of Pneumocystis pneumonia. Emerg Infect Dis 10:1713-1720

3. Mosmann TR, Cherwinski H, Bond MW, Giedlin MA, Coffman RL (1986) Two types of murine helper T cell clone. I. Definition according to profiles of lymphokine activities and secreted proteins. J Immunol 136:2348-2357

4. Jacobson NG, Szabo SJ, Weber-Nordt RM, Zhong Z, Schreiber RD, Darnell JE Jr, Murphy KM (1995) Interleukin 12 signaling in $\mathrm{T}$ helper type 1 (Th1) cells involves tyrosine phosphorylation of signal transducer and activator of transcription (Stat)3 and Stat4. J Exp Med 181:1755-1762

5. Szabo SJ, Jacobson NG, Dighe AS, Gubler U, Murphy KM (1995) Developmental commitment to the Th2 lineage by extinction of IL-12 signaling. Immunity 2:665-675

6. Thierfelder WE, van Deursen JM, Yamamoto K, Tripp RA, Sarawar SR, Carson RT, Sangster MY, Vignali DA, Doherty PC, Grosveld GC, Ihle JN (1996) Requirement for Stat4 in interleukin-12-mediated responses of natural killer and $\mathrm{T}$ cells. Nature 382:171-174
7. Szabo SJ, Kim ST, Costa GL, Zhang X, Fathman CG, Glimcher LH (2000) A novel transcription factor, T-bet, directs Th1 lineage commitment. Cell 100:655-669

8. Kaplan MH, Schindler U, Smiley ST, Grusby MJ (1996) Stat6 is required for mediating responses to IL-4 and for development of Th2 cells. Immunity 4:313-319

9. Hou J, Schindler U, Henzel WJ, Ho TC, Brasseur M, McKnight SL (1994) An interleukin-4-induced transcription factor: IL-4 Stat. Science 265:1701-1706

10. Zheng W, Flavell RA (1997) The transcription factor GATA-3 is necessary and sufficient for Th2 cytokine gene expression in CD4 T cells. Cell 89:587-596

11. Zhang DH, Cohn L, Ray P, Bottomly K, Ray A (1997) Transcription factor GATA-3 is differentially expressed in murine Th1 and Th2 cells and controls Th2-specific expression of the interleukin-5 gene. J Biol Chem 272:21597-21603

12. Garvy BA, Wiley JA, Gigliotti F, Harmsen AG (1997) Protection against Pneumocystis carinii pneumonia by antibodies generated from either $\mathrm{T}$ helper 1 or $\mathrm{T}$ helper 2 responses. Infect Immun 65:5052-5056

13. Cua DJ, Sherlock J, Chen Y, Murphy CA, Joyce B, Seymour B, Lucian L, To W, Kwan S, Churakova T, Zurawski S, Wiekowski M, Lira SA, Gorman D, Kastelein RA, Sedgwick JD (2003) Interleukin-23 rather than interleukin-12 is the critical cytokine for autoimmune inflammation of the brain. Nature 421:744-748

14. Harrington LE, Hatton RD, Mangan PR, Turner H, Murphy TL, Murphy KM, Weaver CT (2005) Interleukin 17-producing CD4+ effector $\mathrm{T}$ cells develop via a lineage distinct from the $\mathrm{T}$ helper type 1 and 2 lineages. Nat Immunol 6:1123-1132

15. Park H, Li Z, Yang XO, Chang SH, Nurieva R, Wang YH, Wang Y, Hood L, Zhu Z, Tian Q, Dong C (2005) A distinct lineage of $\mathrm{CD} 4 \mathrm{~T}$ cells regulates tissue inflammation by producing interleukin 17. Nat Immunol 6:1133-1141

16. Langrish CL, Chen Y, Blumenschein WM, Mattson J, Basham B, Sedgwick JD, McClanahan T, Kastelein RA, Cua DJ (2005) IL-23 drives a pathogenic $\mathrm{T}$ cell population that induces autoimmune inflammation. J Exp Med 201:233-240

17. Dong C (2006) Diversification of T-helper-cell lineages: finding the family root of IL-17-producing cells. Nat Rev Immunol 6:329-333

18. Nurieva R, Yang XO, Martinez G, Zhang Y, Panopoulos AD, Ma L, Schluns K, Tian Q, Watowich SS, Jetten AM, Dong C (2007) Essential autocrine regulation by IL-21 in the generation of inflammatory T cells. Nature 448:480-483

19. Korn T, Bettelli E, Gao W, Awasthi A, Jager A, Strom TB, Oukka M, Kuchroo VK (2007) IL-21 initiates an alternative pathway to induce proinflammatory $\mathrm{T}(\mathrm{H}) 17$ cells. Nature 448:484-487

20. Chung Y, Yang X, Chang SH, Ma L, Tian Q, Dong C (2006) Expression and regulation of IL-22 in the IL-17-producing CD4+ T lymphocytes. Cell Res 16:902-907

21. Liang SC, Tan XY, Luxenberg DP, Karim R, DunussiJoannopoulos K, Collins M, Fouser LA (2006) Interleukin (IL)22 and IL-17 are coexpressed by Th17 cells and cooperatively enhance expression of antimicrobial peptides. J Exp Med 203:2271-2279 